\title{
O Reino esquecido: arqueologia e história de Israel do Norte
}

\author{
Orientadora: Prof $f^{a}$. Maria de Lourdes Corrêa Lima \\ Pesquisadora: Flavia Mendes Serra Nunes \\ Fonte: $\mathrm{CNPq}$
}

Introdução

A região norte do antigo Israel, que constituiu um estado independente do século $\mathrm{X}$ até as últimas décadas do século VIII a.C., apesar de sua relevância econômica, política, cultural e militar, foi pouco valorizada na Sagrada Escritura e na pesquisa acadêmica. Na Bíblia, isso se deveu à perspectiva predominante sulista (Judá) e religiosa com que foram redigidos os textos. Com efeito, nela, a história política do Reino de Israel-Norte recebeu pouca ênfase. Maior espaço foi concedido somente ao reinado de Jeroboão I e Acab (respectivamente, 931-910 e 874-853 a.C.). Por outro lado, Omri e sua dinastia (885-841 a.C.), reconhecidos até mesmo em testemunhos extrabíblicos, não foram contemplados nos textos bíblicos na dimensão que lhes caberia se considerada sua importância histórica.

Nos últimos trinta anos, no entanto, a pesquisa arqueológica sobre o antigo Israel-Norte, desenvolvida pela equipe do professor do departamento de Arqueologia e Civilizações do Antigo Oriente Próximo, da Universidade de Tel Aviv, Israel Finkelstein, trouxe a lume dados que permitiram apresentar, com uma nova impostação, a história do Reino do Norte, abstraindo da visão sulista e religiosa tradicionalmente seguida e predominante. Os dados levantados por sua equipe lançaram nova base para a compreensão da formação do estado do Norte e, com isso, para a avaliação da dimensão histórica e teológica dos textos bíblicos.

\section{Objetivos}

O objetivo de nossa pesquisa foi descrever a situação geopolítica da região do Israel-Norte em sua fase de estabelecimento estatal, durante os 
séculos X e IX a. C. Pretendemos, com isso, lançar luz sobre a dimensão do Reino do Norte e suas características, tanto nos aspectos demográficos quanto nos aspectos sociais e culturais.

Para tanto, analisamos a ocupação cananeia anterior à constituição do Israel-Norte, durante o período do Bronze Tardio e do Ferro I. Nesse sentido, foi necessário investigar a passagem para o regime israelita com a monarquia de Saul e suas relações com estados vizinhos, bem como detalhar a situação cultural, política e econômica do do Reino do Norte do final do século X a. C. até o reinado de Jeroboão I e traçar as características culturais, religiosas, políticas e econômicas da época da dinastia de Omri. 